\title{
Regulating working families in the European Union: a history of disjointed strategies
}

Article

Accepted Version

Busby, N. and James, G. (2015) Regulating working families in the European Union: a history of disjointed strategies. Journal of Social Welfare and Family Law, 37 (3). pp. 295-308. ISSN 1469-9621 doi:

https://doi.org/10.1080/09649069.2015.1081217 Available at https://centaur.reading.ac.uk/44620/

It is advisable to refer to the publisher's version if you intend to cite from the work. See Guidance on citing.

To link to this article DOI: http://dx.doi.org/10.1080/09649069.2015.1081217

Publisher: Routledge

All outputs in CentAUR are protected by Intellectual Property Rights law, including copyright law. Copyright and IPR is retained by the creators or other copyright holders. Terms and conditions for use of this material are defined in the End User Agreement.

www.reading.ac.uk/centaur 
Central Archive at the University of Reading

Reading's research outputs online 


\title{
Regulating Working Families in the European Union: A History of Disjointed Strategies.
}

\author{
Nicole Busby ${ }^{*}$ and Grace James ${ }^{* *}$
}

\begin{abstract}
Families in market economies worldwide have long been confronted with the demands of participating in paid work and providing care for their dependent members. The social, economic and political contexts within which families do so differ from country to country but an increasing number of governments are being asked to engage, or better engage, with this important area of public policy. What seems like a relatively simple goal - to enable families to better balance care-giving and paid employment - has raised several difficulties and dilemmas for policy makers which have been approached in different ways. This paper aims to identify and critique the nature and development of the means by which legal engagement with work-family reconciliation has, historically, been framed in the European Union. In doing so, and with reference to specific cohorts of workers, we demonstrate how disjointed the strategies are in relation to working carers and argue that the EU is unlikely to provide the legal framework necessary to bring about effective change in this fundamentally important area of social policy.
\end{abstract}

Key Words: Reconciliation; work-family; EU, working carers; elderly dependents

\section{Introduction}

In the wake of the devastation caused by World War II, the core aims and objectives of the European Economic Community (EEC) centred on the establishment of a common market one that would function in a way that promoted inter-state cooperation in the pursuit of economic growth: this 'pooling of resources' was viewed as the best way to create economic wealth and 'preserve and strengthen peace and liberty' (Treaty of Rome 1957, preamble). From the outset there was no European system of labour law and the notion that laws would have, as their sole aim, the protection of workers was, even at state level, inconceivable at

\footnotetext{
"nicole.busby@strath.ac.uk

"*.g.james@reading.ac.uk
} 
this time: the Treaty of Rome was 'market making' not 'market correcting' (Caracciolo di Torella and Masselot 2010, p.25, see also Busby 2011 and McGlynn 2006).

Managerial prerogative to hire, discipline or dismiss workers was entrenched across post-war Europe and the typical worker was, following a war-time high in female employment, a full time male under a contract of employment or service. In the 1960s and 1970s working conditions improved where collective action, spurred on by growth in trade union membership and activities, took hold. By the turn of the century an increasing number of women participated in paid employment - notably in the growing service industry, working on fixed term and part-time contracts. There was a growth in marginal workers and welfare provisions had become more stringent and were linked to attempts to secure employment. Changes in the labour markets of Europe and other significant changes in relation to family structures and a growing inclination to challenge gendered constructions of inter-personal expectations (see James 2009, chapter 1) transformed the very work/family landscape that labour laws were seeking to regulate. During this time national labour laws altered significantly. Indeed, in the 60 years following the War 'the labour laws of European countries were transformed almost beyond recognition' (Hepple and Veneciani 2009,p. 4): examples include increased job security with the introduction of protections against unfair dismissal and discriminatory treatment at work, a wealth of health and safety legislation and, importantly, a shift away from reliance upon union activity towards the promotion of individual dispute resolution through judicial procedures (see further Hepple and Veneciani 2009, pp. 21-22).

During this period of significant change at national levels the EEC was transformed into a larger union, widening geographically to include new Member States and deepening as a new European legal order was created. Within this new European Union, the significance of workers and their families gradually received greater attention although unsurprisingly concern for working carers, when attention did arrive, was patchy and inconsistent and constructed, along with broader social goals, as 'side issues to achieving greater economic integration' (Caracciolo di Torella and Masselot 2010, p. 25). Hence within the EEC, and later the European Community (EC), reconciliation of work and family life was developed only as a necessary adjunct to broader policy concerns, primarily gender equality and 
economic agendas such as free movement and, later, as part of a growing allegiance to human rights discourse. More recently, it has become subsumed within the 2020 strategy of full employment (European Commission 2010a). Significantly, at no point in the history of Europe has work-family reconciliation been a core policy goal in its own right.

Whilst legal developments at the supranational level have undoubtedly helped to improve the lives of working carers across Europe, there is no coherent evolution in terms of the legal regulation of working carers, but rather an ad-hoc, often weak and highly gendered longitudinal engagement with work-family issues. In operational terms, as McGlynn (2001b) has noted "the EU's approach [to the reconciliation of paid work and family life] is actually one dominated by rhetoric and symbolism at the expense of action" (p. 242). This article demonstrates how this legal framing of work-family reconciliation varies in terms of nature, scope and pace of progress across a spectrum of key 'work-family' related areas. Reconciliation policies have been constructed upon the foundations of a project - the creation of a united Europe - that is principally economically focussed and sensitive to political factors. It concludes that, despite some important contributions to the legal rights available to the citizens of Europe, progress at this level has stagnated and is likely to continue to be patchy and inadequate. Indeed, with the impact of recession, austerity cuts (see Guerrina in this issue) and the EU's own existential crisis, it seems increasingly unlikely that the EU will ever provide the supranational legal rights and protections necessary to significantly improve the lives of working carers and the recipients of their care. In order to substantiate this core observation this article will consider policy developments in relation to key - and often overlapping - cohorts of workers namely, pregnant workers and mothers returning to work following maternity leave, working parents and workers with elderly dependants. Before doing so we provide a broad consideration of the policy development of work-family reconciliation in the EU.

\section{Policy Development of Work-Family Reconciliation in the EU}

EU regulation aimed at enabling parents and others to manage the conflicts encountered in juggling the demands of paid work and care-related commitments has historically linked the goal of gender equality with the development of social policy under the banner of "work- 
family reconciliation'. The relationship between the attainment of equality, through an equal opportunities approach, and better workplace facilitation of unpaid care commitments has not always produced the sort of positive outcomes that a different policy trajectory could have secured. However, the linking of these two strands and their adoption in pursuit of wider macroeconomic goals tells the story of the EU's chronology of social policy development.

In 1957 the Treaty of Rome established the EEC's commitment to equal opportunities through its inclusion of Article 119 which provided for 'equal pay for equal work'. From this marginal beginning, the concept of gender equality was developed through specific policy fields during the 1970s and 1980s (Busby 2011). Following a failed attempt to harmonise what had become known as the EU 'social dimension' in the late1980s (Streeck 1996), social policy remained largely a matter reserved to Member States as opposed to economic policy and competition law which were developed at EU level to facilitate market integration. By the 1990s, changes within the labour market and to family formation and social arrangements had led to a series of demographic, economic and fiscal challenges to the Member States' welfare systems (Pierson 2001). The increasing focus on work and family reconciliation had been catalysed by the EU's attempts to respond by legislative and policy means to these combined challenges so that, "The growing willingness to address family care issues insofar as they impinged on labour market participation, especially of women, was as much a part of these considerations as the equal opportunities agenda' (Lewis 2006).

However, towards the end of the 1990s gender equality in employment and work-family reconciliation were becoming disentangled from the previously related field of social policy, with the loss of the legislative approach which had hitherto been a feature of their unification. The extended scope of equality law by the Treaty of Amsterdam's insertion of Article 13 into the former Treaty Establishing the European Community (now Article 19 Treaty on the Functioning of the EU (TFEU)) to include 'discrimination based on racial or ethnic origin, religion or belief, disability, age or sexual orientation' meant that the exclusive focus on gender was lost, leaving 'equality policies at a critical juncture' (Mazey 1998, p. 148). Gender equality's status as a priority legislative target was replaced with a softer approach so that its promotion was largely through 'mainstreaming' across all policy areas (Rees 1998). Furthermore, as a result of the dual pressures of internal enlargement and increasing global 
competition, the realisation of social policy objectives through the development of specific hard law measures was becoming a thing of the past.

In 1997 the Amsterdam Treaty's redrafting saw 'Employment' bestowed with a separate Title within the Treaty so that it was afforded equal status with 'Economic and Monetary Policy' and 'Social Policy'. Although this opened the way for the concept of work-family reconciliation to be more firmly embedded into employment policies through the European Employment Strategy (EES) (European Commission, (2010)a, enforcement through top down compliance with Directives was replaced by the soft law approach of the Open Method of Coordination (OMC) (Ashiagbor 2005). The OMC required Member States to participate in the setting of common objectives monitored through a process of peer review. The demise of the traditional legislative approach and what was, in effect, the end of the EU's programme of social policy harmonisation has been the subject of criticism due to the competing objectives that emerged under the framework of the EES. Although enhanced competitive efficiency within enterprises, greater labour market flexibility and an increased employment rate may be easily achieved through the use of non-standard work, the accompanying rise in precariousness was at odds with the dual aim of enhanced protection of and improvements in workers' quality of life and work life balance (Ashiagbor 2006, p. 77).

Now, in the post-Lisbon landscape, Article 3(3) of the TEU contains certain relevant constitutional promises including 'full employment and social progress', to 'combat social exclusion and discrimination' and to 'promote social justice and protection, equality between women and men, solidarity between generations and protection of the rights of the child.' These aspirations must now be read alongside the newly enshrined fundamental right provided by Article 33(2) of the EU Charter of Fundamental Rights (CFR) to 'reconcile family and professional life' by which 'everyone shall have the right to protection from dismissal for a reason connected with maternity and the right to paid maternity leave and to parental leave following the birth or adoption of a child.' At first sight, Article 33(2) might appear to offer a renewed commitment to reconciliation of work and family commitments but, in actual fact, all it provides is a careful codification of the pre-existing provisions on maternity and parental leave which, as the following sections will demonstrate, simply reinforces the differential levels of protection in relation to each. Moreover, as the current 
Employment Guidelines (European Commission, 2010b) demonstrate, the dual goals of gender equality and work-life balance have now become completely absorbed into the overarching strategy of improving supply side factors in the pursuit of macroeconomic targets. Guideline 7 'Increasing labour market participation and reducing structural unemployment' provides that,

'...In order to increase competitiveness and raise participation levels... Member States should increase labour force participation through policies to promote active ageing, gender equality and equal pay and labour market integration of young people, disabled, legal migrants and other vulnerable groups. Work-life balance policies with the provision of affordable care and innovation in work organisation should be geared to raising employment rates, particularly among youth, older workers and women...'

During the forty years in which work-family reconciliation has emerged as part of Europe's policy agenda we have witnessed its decline in value - it no longer provides a beacon of hope with a promise to deliver better lives for working carers across Europe, particularly where national policies are failing. Rather, it has become centrally constructed as a core means of delivering a broader objective of full employment. Policy agendas are paramount in this field, not least because the EU provides a unique platform for information sharing and knowledge exchange. However, whilst recognising the contribution of this aspect of European integration, we will undoubtedly mourn the time when the EU was a proactive and innovative force in this critical area of social policy.

\section{Pregnant Workers and Mothers Returning to Work Following Maternity Leave}

Pregnant workers and mothers returning to work following maternity leave have been the core focus of two important Directives: the Equal Treatment Directive 76/207/EEC (ETD) of February 1976 and the Pregnant Workers Directive of 92/85/EEC of October 1992 (PWD). The ETD was 'one of the foundation stones of EU law and policy in the area of gender equality' (Masselot, Caracciolo di Torella and Burri 2012, p. 4). Amended several times and now part of the Recast Directive 2006/54/EC, this provision altered the face of legal engagement with pregnant workers and new mothers returning to work across Europe. Of particular significance is Art 2(2)(c) which prohibits 'any less favourable treatment of women 
related to pregnancy or maternity leave' and which has been generously interpreted by the Court of Justice of the European Union (CJEU) over the years: an interpretation that has since been acknowledged in Recitals 23 and 25 of the Recast Directive.

The CJEU's early, purposive approach is epitomised most clearly in the case of Dekker (Case C-177/88 [1990] ECR I-3941) where it held that the absence of a male comparator in relation to pregnancy-related discrimination was not capable of defeating the claim (for comment see Barnard 1995; Ellis 1994; McGarry 1995 and for further discussion and critique of the development of the Court's jurisprudence in this area see, for example, Caracciolo di Torella and Masselot 2001 and 2010, Guerrina 2005; McGlynn 2006). However, whilst the Court has promoted substantive equality (see for example, Case 136/95Thibault [1998] ECR I2011 and Case 207/98 Mahlburg [2000] ECR I-549) and positive progress has been made as a result of the rulings of the CJEU in relation to pregnancy and maternity, commentators have become increasingly reluctant to conclude that the ends always justify the means. In brief, many of the rulings, although they have extended rights to working women, have been de facto rooted in outdated ideologies of motherhood (see McGlynn 2001a) and fatherhood (Caracciolo di Torella 2014). Examples include a ruling in the early case of Commission v Italy (Case 163/82 [1983] ECR 3273) that a piece of Italian legislation that only granted leave to mothers following adoption, was not contrary to the EC law. The Court promoted gender specific provisions in the event of adoption, which it justified on the grounds that it wanted to 'assimilate' the conditions of entry into the family to those of a new born baby (para.2). In a similar vein, in Hofmann (Case 184/83 [1984] ECR 3047) the CJEU endorsed the payment, in Germany, of state benefits only to mothers, even though care-giving in this particular case was being provided by the father from the age of eight weeks to six months. The Court stated that the relevant EU law was 'not designed to settle questions concerning the organization of the family, or to alter the division of responsibility between parents' (at para.1). This ruling has since been questioned in Roca Alvarez v Sesa Start Espana ETT SA (Case C 104/09 [2011]), where a less gendered approach was taken (see below). In the case of Lommers (Case C-476/99 [2002] ECR I-2891) the CJEU supported the exclusive use of childcare facilities for mothers at the Netherland's Ministry of Agriculture, which meant that a male employee could not bring his child to the nursery. Criticised for not assessing the potential impact of this policy on the child's wellbeing and the fact that it undermined the parent's choices regarding childcare facilities (see James 2013), this case reflects how policies and laws that purport to promote gender equality can backfire and fail to support the needs of 
returning mothers and their families. Each of these cases demonstrates the limited approach of the CJEU. This was also indicative in the case of Sabine Mayr (Case 506/06 ECR I-1017 [2008]) where a woman was dismissed when undergoing IVF treatment. The CJEU ruled that treatment for in vitro fertilisation 'directly affects women only' (see, para 50), a ruling that benefitted the claimant in this case as it brought her procedure within the protection of relevant EC law, but fundamentally disregarded the importance of both parents in IVF (see James 2009: 54). More recently, in the case of C.D. v S.T (C-167/12 [2014] see Caracciolo di Torella and Foubert 2015) the Court denied maternity or adoption leave and pay to a mother who has a baby as part of a surrogacy arrangement - maintaining that this approach did not breach EC law.

The CJEU cases, as a whole, reflect the limitations of equality-based laws to adequately address the more controversial aspects of work/family reconciliation (see James 2009, p. 53). The CJEU approach is understandable, providing a direct and logical link between the situations that arise and the ETD and thereby concretising rights for the cohort in question and supporting the gender equality aims of the provision. However, the approach is frustrating because the CJEU has shown itself to be capable of reflecting the more subtle changes that have occurred in society (see the different approach taken in Roca Alvarez $v$ Sesa Start Espana ETT SA (Case C 104/09 [2011] but see Case C-5/12 Betriu Montull, [2013] 571 and Caracciolo di Torella in this issue) for example, and for a general discussion of the CJEU's potential to facilitate change in this area see Busby, 2011, pp 135-139). Supporting outdated ideologies of motherhood and fatherhood restricts any potential progress towards a more gender neutral construction of caregiving (see also Busby and James 2016, forthcoming).

Alongside the ETD and its limited application, there was, however, a further piece of legislation that attempted, in a different but connected way, to enhance the lives of pregnant workers and new working mothers: the PWD, this time based upon Art 118a EC (now Art 137 TFEU). The purpose of this Directive is fairly broad, being 'to implement measures to encourage improvements in the safety and health at work of pregnant workers and workers who have recently given birth or who are breastfeeding' (Art 1). It provides the 'pregnant worker', 'worker who has recently given birth' and 'worker who is breastfeeding', all of which are defined nationally, with minimum rights including protection against exposure to 
harmful substances and processes when pregnant or breastfeeding; protection against any obligation to undertake night work; paid time off to attend antenatal appointments; entitlement to 14 weeks minimum maternity leave, 2 weeks of which need to be compulsory and payment for which is subject to eligibility criteria to be laid down at national level but must be at least equivalent to sickness benefits; prohibition against dismissal during the 'protected period' (Art 10); and the ability to defend these rights through a judicial process.

There have been some minor amendments to the PWD - mostly in relation to reporting procedures and updates regarding known hazardous substances (listed in Annex 2 of the original Directive), but a more significant proposal to amend the PWD was sadly defeated. The European Parliament proposal (COM (2008) 637 Final), which sought to use a combination of health and safety (Article 137 TFEU, previously 118a EC) and equality (Art 141(3) TFEU) as its legal base, demonstrating how the distinction between the two had blurred over time within this context, would have improved the legal framework in a number of modest but important ways. It proposed, for example, to extend maternity leave allowance to 18 weeks at full salary (to reflect the duration of leave recommended by the International Labour Organisation); to introduce a new right to paternity leave; a right to return to work under equivalent or improved conditions; a right for returning mothers to request a reconsideration of their working hours; and that any breach of the Directive be considered discriminatory with the (recommended) use of dissuasive penalties for non-compliance.

The defeat of this - not particularly radical - proposal was disappointing. In fact many of its provisions corresponded closely with the legal frameworks already adopted by Member States (see Masselot et al. 2012). Its provisions would also have aligned the legislation with the CJEU's case law. The decision not to support the proposal was, according to the Council of the EU, due to 'the broad diversity of maternity protection and social security amongst the Member States... [and] the financial implications, especially during the crisis' (Council of the European Union 2011). It is hard to envisage a time when such diversity between Member States will not exist - EU legislation was indeed perceived as being key to achieving a minimum floor of rights across Europe. What this defeat perhaps demonstrates most strongly is the reprioritisation and downgrading of EU work-family reconciliation policy 
within an enlarged Europe faced with economic constraints (but see Foubert and Imamović in this issue).

At present, the legal framework protecting pregnant and new mothers at work is fairly stagnant. The demise of the 2008 proposal reflects the fragility of work-family policies in times of economic crisis when, ironically, pregnant and new mothers appear to be especially vulnerable to unlawful dismissal and poor treatment at work (see Masselot et al. 2012,pp. 1617 and, for recent evidence in the UK, see Gentleman , 2011; for a more general discussion of the impact of austerity on gender equality see Karamessini and Rubery 2014). In sum, whilst EU intervention has undoubtedly provided useful, practical protection to many women, its long term ability to provide enhanced support for pregnant and new mothers who continue to face unacceptably high levels of poor treatment at work (Masselot et al. 2012), appears fundamentally weak and uninspiring.

\section{Working Parents}

The EU's identification of working parents as a group requiring specific legislative attention can be traced back to the early days of the CJEU's case law on the applicability of antidiscrimination law to part-time work (starting with Case 96/80 Jenkins v Kingsgate (Clothing Productions) Ltd ECR 911; for a full discussion of this case law, see Busby 2011, Ch. 6). These cases concerned women part-time workers whose need to balance care commitments with paid employment resulted in reduced employment protection and less favourable workplace entitlements than full-time workers. By highlighting the fact that (female) workers with care commitments often found themselves situated quite differently from the unencumbered (male) 'standard worker', the cases revealed the limitations of the equal treatment approach due to its underlying assumption that a 'like with like' comparison was always possible as a means of identifying and remedying inequality on the grounds of sex. The spotlight that had been thrown on the structural inequalities faced by working carers culminated in a social partners' framework agreement on part-time working and the introduction of Council Directive 97/81 (O.J. [1992] L123/16) which is specifically targeted at equalising terms and conditions between part-time and full-time workers. The initiative was followed by a further agreement and directive (Council Directive 1999/70/EC) aimed at 
equalising terms and conditions for those employed on fixed-term and permanent contracts. Despite their well-documented limitations (see, for example, Lyonette this issue on Directive 97/81/EC), such initiatives have undoubtedly provided assistance and support for working parents not least by shifting the focus of their protection away from sex discrimination and thus breaking the essentialist connection between 'women's work' and unpaid care. This approach has been further developed through the provision of a specific right to parental leave which will be the focus of this article.

Alongside gender equality, the provision of rights for working parents has developed in response to a range of policy challenges including low fertility rates and the need to increase competitiveness and economic growth. One danger of this shifting policy focus is that objectives such as equality, become subsumed by the 'dominant policy preoccupation' (Lewis 2006, pag. 5; see also Pollack and Hafner-Burton 2000, p. 440). In the promotion of work-family reconciliation the gender equality goal became subsidiary to the overriding objective of economic growth through full employment (Stratigaki 2004). This view is supported by a close analysis of the statutory parental leave scheme which, despite pledging equalisation of care commitments between parents has, in practice, reaffirmed the gendering of care by leaving too much to Member States' discretion. The result of this shifting agenda has, thus, been a somewhat patchy and piecemeal development of reactive, rather than proactive, policy which focuses on the paid work, rather than the unpaid care, aspect of the conflict experienced by working parents (Busby 2011, Weldon-Johns 2013). Whereas working mothers have suffered disadvantage in attempting to fit care commitments into often unyielding workplace structures built around the 'standard worker' model of a bygone era, working fathers have been faced with little acknowledgement of their involvement with their children (see Caracciolo di Torella in this issue), all within a policy field which is underpinned by heteronormative gendered assumptions regarding the organisation of work and family life (Mazey 2000, Bacchi 2004, Busby 2011).

The first legislative attempt at encouraging the sharing of gender-neutral care by working parents was the Parental Leave Directive 96/34/EC which was subsequently replaced by a revised Directive 2010/18/EU. Although the later Directive was intended to address some of the shortcomings of its predecessor, any improvements have had a marginal effect in practice. 
Directive 96/34 had a difficult and contentious beginning with agreement finally reached on the basis of a series of compromises which weakened its ability to achieve its original objectives (Weldon-Johns 2013, p.7) Although the aim of encouraging shared parenting was preserved and explicitly referred to in the Framework Agreement on Parental Leave annexed to Directive 96/34 (General Considerations, 7 and 8) through recognition of the need to encourage men to 'assume an equal share of family responsibility' (Framework Agreement, para 1(8)), the rights themselves merely imposed minimum standards leaving much of the operational detail to Member States including the critical issue of payment with Clause 2(8) merely specifying that matters relating to social security should be determined by the Member States in accordance with national law. The effect of this approach was that, although the Directive ostensibly recognised that care need not be the exclusive responsibility of women by giving equal rights to both parents, its reliance on pre-existing national welfare systems left the status quo firmly intact preventing it from being a policy-leader (Caracciolo di Torella 2000a). The ability of the legislation to achieve its equality objectives was, thus, compromised as was its ability to harmonise parental rights across Europe (Hardy and Adnett 2002, p.169).

Even without its reliance on implementing measures, the rights provided by the Directive were never going to challenge the division of care at the household level. The unpaid nature of the leave, its non-specified length - Clause 2(2) merely provided for a minimum of three months - and temporal limitation to a child's eighth birthday as well as the potential for transferring leave between parents have been identified as contributing to its reaffirmation of the gendering of care (Caracciolo di Torella 2000b, Weldon-Johns 2013 p. 8). The continued focus on the period following childbirth and the leave's use as an alternative to extended maternity leave in some Member States (European Commission 2003), meant that the Directive was unable to deliver on its shared parenting objective.

In their renegotiated Framework Agreement on Parental Leave of 18 June 2009 (annexed to Directive 2010/18), prima facie the social partners made some significant improvements which were incorporated into Council Directive 2010/18/EU which repealed and replaced Directive 96/34 in March 2012. The new Directive's Preamble identifies parental leave as 'an important means of reconciling professional and family responsibilities and promoting equal 
opportunities and treatment between men and women'. As well as extending its provisions to adoptive parents (Clauses 2(1) and 5), and to all those with an employment contract or relationship, (Clauses 1(2) and (3)), Directive 2010/18 increased the length of leave available from three to four months, one month of which is strictly non-transferable and will be lost if not taken (Clause 2(2)). In addition, the Directive introduced a right to request a flexible work arrangement on returning from parental leave (Clause 6(1)) and provided enhanced protection against dismissal and other detriments as a result of using the rights (Clause 5(4)). However, despite these improvements, the revised Directive, like its predecessor, left too much open to interpretive implementation by Member States. One obvious example of this is the non-transferability of only one months' leave which is unlikely to do very much by way of incentivising fathers to provide care beyond that limited period. Other issues for Member State determination are the establishment of the notice periods required by workers in exercising their rights to parental leave (Clause 3(2)), and the option to maintain a qualifying period of a maximum of one year (Clause 3(1) (b)) which seriously undermines the extension of the right to parental leave to all workers regardless of contractual status. Most disappointingly, the revised Directive did nothing to address the issue of pay which remains a matter for Member State determination.

The discretion given to Member States has led to a lack of clarity and left a number of unresolved issues, some of which have been considered by the CJEU. Given the legislation's scant guidance regarding pay, the Court has unsurprisingly been asked to rule on the costs of parental leave and related payments and benefits. In its judgment in an early case brought under Directive 96/34, the Court was criticised for reinforcing gender stereotypes in line with its pregnancy and maternity-related jurisprudence outlined above. In Lewen $v$ Denda (C333/97 [1999] ECR I-7243) the Court was concerned with whether eligibility for a Christmas bonus whilst on parental leave was consistent with Clause 2(6) which provided that rights acquired at the start of a period of leave 'shall be maintained as they stand until the end of parental leave.' The Court held that eligibility arose by virtue of the claimant's gender rather than the provision of any specific right to the payment as women are likely to be on parenting leave far more often than men so that their exclusion would amount to indirect sex discrimination. By reinforcing the view that childcare is primarily the responsibility of mothers, the Court undermined the Directive's shared parenting objective and gave no benefit 
to either sex consigning women to reliance on sex-specific criteria for recognition of their rights and leaving men with a reduced level of protection (Caracciolo di Torella 2000a).

As parental leave demonstrates, EU provision in this area is rife with inconsistencies due to the absence of a cohesive policy and legislative strategy. The fact that payment for parental leave remains a matter for Member States' determination has led to a diversity of arrangements so that, although most states offer some form of payment, the rate varies from $30 \%$ of salary in Italy to $100 \%$ in Denmark with eight countries, including the UK, providing no payment (Eurofound 2015, p. 2). Thus, although the rate of fathers' take-up is increasing in most Member States, it is 'generally still relatively low' (Eurofound 2015, p. 3), with leave compensation identified as a key influencing factor (Eurofound 2015, p. 5).

Despite continued reference to family leave in policy documents, there is little cause for optimism regarding further progress. The European Strategy for Equality between Women and Men 2010-2015 (European Commission 2010c) identifies five priorities, one of which is 'equal economic independence' under which the Commission pledges to '[a]ssess remaining gaps in entitlement to family-related leave, notably paternity leave and carers' leave, and the options for addressing them'. It goes on to specify that 'Social partners will be consulted on further measures, under Article 154 TFEU' (at 6). In the last year of the period covered by the strategy, no discernible progress has been made in this respect so that 'Leave from work related to the birth of a child still tends to be strongly associated with mothers while less attention seems to be paid to the fathers' situation.' (Eurofound 2015 p.10). Meanwhile, the CJEU has held that EU law does not grant any rights to transferable parental leave to an employed father unless the mother is also employed (Case C-5/12 Montull $v$ Instituto Nacional de la Seguridad Social [2014] 1 CMLR 35), thus reaffirming the association between parental rights and maternal care and the derivative nature of fathers' entitlement in this area.

\section{Workers with elderly dependants}


We have, so far, focussed on the legal rights and protections available to carers - or, in the case of pregnant workers, potential carers - of children. This is the area in which the EU and the majority of national frameworks are most developed. However, an increasing number of workers care for elderly or disabled dependants and, as Horton (in this issue) suggests, demographic shifts within the EU mean that regulation affecting this cohort of working carers needs to be reassessed (James and Spruce 2015). As would be expected, despite country specific variations, care-giving is more prominent among female workers and among those within the 50-64 age group (see e.g. Eurostat 2005, Herring 2009). However, the EU population is ageing (European Commission 2015) and what has been constructed as a 'longevity revolution' (Butler 2008), a 'perfect storm' (Schroeder, Macdonald and Shamian 2012) or a 'generation strain' (McNeil and Hunter 2014) is now a global phenomenon that cannot be ignored.

Yet, as the population ages, we are witnessing a decasualisation of this type of care so that 'informal' eldercare - a term that for all intents and purposes means unpaid and unsupported is no longer absorbed, unnoticed, into private family life. Simultaneously, many countries have reduced the level of community care provision available for eldercare and, due to changes in pension provisions and retirement laws, workers are required to stay in the labour market for longer (Herring 2009, 2013). Hence most workers will inevitably have to undertake some informal care at some point in their working life and, indeed, most individuals will, at some stage, require such care. Policy makers are, thus, increasingly challenged by the growing need to accommodate this latest 'care-giving conundrum' (James and Spruce 2015).

Given the growth in informal eldercare across the EU, the lack of legal engagement is of increasing concern, impacting on the wellbeing of carers, the recipients of their care, employers and welfare states across the EU. The only concrete provision in place at EU level is for a very short term emergency leave - an entitlement available for an 'urgent family reason' only (Clause 7 Parental Leave Directive 2010/18). Carers can, if they and their particular circumstances are eligible, gain some protection under the anti-discrimination provisions. For example, indirect sex discrimination might be claimed if a 'provision, criterion or practice' disadvantages a (female) carer but only because the majority of carers 
are women - a demographic that data (see above) suggests might shift in the future making this protection inapplicable. The CJEU has also extended the ambit of anti-discrimination laws relating to disability so as to include those associated with the disabled person (see C303/06 Coleman v Attridge Law [2008] ECR I-5603 - but see also discussion by Connor 2010 and Horton this issue). Interestingly, the wellbeing of the elderly also features in the European Charter of Fundamental Rights, which endorses recognition and respect for 'the rights of the elderly to lead a life of dignity and independence and to participate in social and cultural life' (Art. 25), a recognition that, if we wish to sustain the essential contribution of informal care, requires better engagement with the role of carers in this endeavour.

Beyond these ad-hoc, unfocussed and disjointed legal developments, there has, over the years, been a steady trickle of other 'soft' initiatives by the Commission and the Parliament seeking to raise the profile of and, in the case of the latter, encourage greater policy support in relation to workers with eldercare responsibilities; examples include the European Commission Consultation on Carers Leave in 2011 (European Commission, 2011) and the European Parliament's Resolution in 2013 calling for a Directive on carer's leave (European Parliament, 2013). Overall though, it is clear that, at present there is little appetite for change in this area and it is, for the most part, perceived as a policy matter for Member States. In many ways this cohort of workers is a recent addition to the work-family reconciliation radar, and joined at a time when the EU had already framed work-family issues as being linked to gender equality and associated economic goals such as full employment. Hence, the needs of such workers are an awkward fit and the conundrum they present exposes, once more, EU policy's inherent limitations in this field. Whilst work/care issues are likely, for the foreseeable future, to impact upon women more than men it is going to be difficult and arguably counter-productive in the long term to construct eldercare as a gender equality issue. The demographic trajectory will simply require more men as well as women to care for their elderly relatives, and constructing it as a gender issue is unhelpful. There is no 'special relationship' that can provide a simplistic and gendered rationale for action in this context although the Commission clearly sought to emphasise the weighted impact of eldercare upon women in its justification for a call for action under Article 157 (European Commission 2011). 
The impact of eldercare upon labour market participation and citizen wellbeing clearly requires further attention at an EU level - attention that need not be restricted to policy initiatives. For example, an EU-funded report by Cullen and Gareis (2011) provides detailed information on company initiatives for workers with care responsibilities for disabled children and adults within Member States, and provides useful insights into the realities of working life for this cohort. Various formal and informal company-level measures were explored, including leave provisions, flexibility in work practices, use of occupational health services and improving understanding amongst supervisors and colleagues. Overall the study demonstrates how many carers "continue to experience excessive strain from juggling [the] two roles, with negative implications for their health, their quality of working life, their family and personal lives and their careers" (Cullen and Gareis 2011, p. 73). It concludes that "explicit attention to the needs of working carers is still far from the norm and generally seems to be very uncommon at the company level" (Cullen and Gareis 2011, p. 75) and that without adequate support within workplaces, we risk damaging employment rates or losing the contribution informal carers provide. Such studies are hugely valuable, especially given the recent downgrading of work-family reconciliation policies within the EU legal framework; a process that has shifted the burden for improving the lives of working carers back to Member States, making cross-national awareness raising and information sharing crucial.

\section{Conclusion}

In the contemporary context, a meaningful commitment to improve the lives of working carers and the recipients of their care, as with most labour law initiatives, would best be achieved through a cohesive social welfare approach. However, this is not an area of primary concern for the EU which lacks legal competence in this respect. Consequentially, and with the increasing influence of combined factors such as enlargement, globalisation and the EU's current existential crisis, work-family policies are likely to continue to be pushed back to Member States for the foreseeable future with any development at EU-level, along with labour laws in general, unlikely. As Hepple and Veneviani (2009 p. 29) put it,

'in the future, as in the past, the crucial element in both the making and the transformation of labour law will be the power of capital, and countervailing power of organised labour and civil society - workers, consumers and active citizens'. 
Through their EU membership, the regulation of labour within Member States has been transformed over the past 40 years, initially through the important recognition that without social development economic integration would not be possible. However, more recently, the economic crisis has emerged as the dominant force in the development of EU labour law and policy (see Braun and Hepple 2009). Increased competition from developing countries with fledgling regulatory systems which offer minimal social protection, coupled with the internal strains provoked by its own enlargement, have led to a retrenchment in the development of labour law generally. In this changed context, a core question will be how the EU can maximise its potential to contribute to and influence improvements in both the working conditions and lived experiences of carers and their dependants. As this article demonstrates, the EU's engagement with work and family reconciliation, never articulated as a cohesive strategy and operationally-driven to fulfil related but distinct economic objectives, is simply not robust enough to weather this storm, at least in its current form. Despite the fact that the goal of work and family reconciliation is far from achieved, the next forty years of the EU's engagement in social policy-making is likely to see the completion of its evolution from policy innovator to facilitator. Regretfully it would, thus, appear that the EU's most important work in the current context is behind it.

\section{Bibliography}

Ashiagbor, D. 2005. The European Employment Strategy: labour market regulation and new governance. Oxford: Oxford University Press.

Ashiagbor, D. 2006. Promoting precariousness? The responses of EU employment policies to precarious work In: J. Fudge and R. Owens, eds, Precarious work, women and the new economy: the challenge to legal norms. Oxford: Hart Publishing, 54-77. 
Bacchi, C. 2004 Policy and discourse: challenging the construction of affirmative action as preferential Treatment. Journal of European Public Policy, 11 (1), 128-46.

Barnard, C. 1995 EC employment law. London: Chancery Law Publishing.

Braun, N., and Hepple. B 2009. Economic policy and labour law In B. Hepple and B. Veneciani, eds, The Transformation of Labour Law in Europe. Oxford. Hart Publishing, 3157.

Busby, N. 2011. A Right to care?: unpaid care work in European employment law. Oxford: Oxford University Press.

Busby, N. and James, G. 2016 forthcoming. A history of regulating working families: strategies and stereotypes, strains and solutions. Oxford: Hart Publishing.

Butler, R. 2008. The longevity revolution: the benefits and challenges of living a long life. New York: Public Affairs.

Caracciolo di Torella, E. 2000a. Childcare, employment and equality in the EC: first (false) steps of the Court. European Law Review, 25, 310-316.

Caracciolo di Torella, E. 2000b. A critical assessment of the EC legislation aiming at reconciling work and family life: Lessons from the Scandinavian Model. In H. Collins, P. Davies, and P. Ridout, eds. Legal Regulation of the Employment Relation. London: Kluwer Law International, 441-457. 
Caracciolo di Torella, E., 2014. Brave New fathers for a brave new world? Fathers as caregivers in an evolving European Union. European Law Journal, 20(1), 88-106.

Caracciolo di Torella, E. and Foubert P. 2015. Surrogacy, Pregnancy and Maternity Rights: A Missed Opportunity For a More Coherent Regime of Parental Rights in the EU? The European Law Review 40(1), 52-69.

Caracciolo di Torella, E. and Masselot, A. 2001. The ECJ case law on issues related to pregnancy and maternity: an attempt of classification, European Law Review, 26, 239-260.

Caracciolo di Torella, E. and Masselot, A. 2010 Reconciling work and family life in EU law and policy. London: Palgrave Macmillan.

Connor, T. 2010. Discrimination by Association: A step in the right direction. Journal of Social Welfare and Family Law, 32(1), 59-69.

Council of the European Union, 2011. Proposal for a Directive of the European Parliament and of the Council amending Council Directive 92/85/EEC on the introduction of measures to encourage improvements in the safety and health at work of pregnant workers and workers who have recently given birth or are breastfeeding - Progress Report. SOC 1002/SAN 246/CODEC 2061.

Cullen, K and Gareis, K. 2011. Company initiatives for workers with care responsibilities for disabled children or adults. Luxembourg: Publications of the European Union.

Ellis, E. 1994. The definition of discrimination in European Community sex equality law. European Law Review, 19, 563-580. 
Eurofound, 2015. Promoting uptake of parental and paternity leave among fathers in the European Union. Luxembourg: Publications of the European Union.

European Commission, 2003. Report on the implementation of Council Directive 96/34/EC of 3rd June 1996 on the framework agreement on parental leave concluded by UNICE, CEEP and the ETUC. (COM(2003) 358 final). Brussels.

European Commission, 2010a. Europe 2020, A European strategy for smart, sustainable and inclusive growth. Brussels.

European Commission, 2010b. Europe 2020, Integrated guidelines for the economic and employment policies of the member states. Brussels, 27.4.2010 SEC(2010) 488 final.

European Commission 2010c. Communication from the Commission to the European Parliament, the Council, the European Economic and Social Committee and the Committee of the Regions of 21 September 2010 - Strategy for equality between women and men 20102015. Brussels, [COM(2010) 491 final

European Commission, 2011. Roadmap: reconciliation between work, family and private life. Brussels.

European Commission, 2015. The 2015 Ageing report; underlying Assumptions and Projection Methodologies. Brussels

European Parliament, 2013. Resolution of 4 July 2013 impact of the crisis on access to care for vulnerable groups. Brussels.

Eurostat, 2005. Labour force survey annual dataset. Luxembourg. 
Gentleman, A. 2011., Pregnant? Wait 'til the boss hears. The Guardian, June 23.

Guerrina, R. 2005. Mothering the union. Manchester: Manchester University Press.

Hardy, S. and Adnett, N. 2002. The Parental Leave Directive: towards a "family-friendly" social europe? European Journal of Industrial Relations, 8(2), 169-170.

Hepple, B. and Veneciani, B, eds. 2009. The transformation of labour law in Europe. Oxford: Hart Publishing.

Herring, J. 2009. Older people in law and society. Oxford: Oxford University Press.

Herring, J. 2013. Caring and the law. Oxford: Hart Publishing.James, G., 2009. The legal regulation of pregnancy and parenting in the labour market. London: Routledge.

James, G. 2013. Forgotten children: work-family reconciliation in the EU. Journal of Social Welfare and Family Law, 34 (3), 363-379.

James, G and Spruce, E. 2015. Workers with Elderly Dependants: Employment Law's Response to the Latest Care-giving Conundrum. Legal Studies, Advance Online Publication. doi: 10.1111/lest.12073

Karamessini, M., and Rubery, J. 2014. Women and austerity: the economic crisis and the future for gender equality. London: Routledge. 
Lewis, J. 2006. Work/family reconciliation, equal opportunities, and social policies: the interpretation of policy trajectories at the EU level and the meaning of gender equality. Journal of European Public Policy, 13 (3), 420-437.

Masselot, A., Caracciolo di Torella, E., and Burri, S. 2012. Fighting discrimination on the grounds of pregnancy, maternity and parenthood: the application of EU national law in practice in 33 european countries. European Commission. .

Mazey 1998 'The European Union and women's rights: from the europeanization of national agendas to the nationalization of a European agenda?' Journal of European Public Policy $5(1), 131-152$.

Mazey, S. 2000. Introduction: integrating gender - intellectual and "real world" mainstreaming. Journal of European Public Policy, 7 (3), 333-345.

McGarry, T. 1995. Maternity rights in Northern Ireland: the Struggle to achieve equality of opportunity. Review of Employment Law Topics, 3(1), 309-334.

McGlynn, C. 2001a Reclaiming a feminist vision: the reconciliation of paid work and family life in European Union law and policy. Columbia Journal of European Law, 7 (2), 241-272.

McGlynn, C. 2001b. European Union family values: ideologies of "family" and "motherhood" in European Union law. Social Politics, 8(3), 325-351.

McGlynn, C. 2005 Work, family and parenthood: the European Union agenda. In: J. Conaghan and K. Rittich, eds. Labour Law, Work and Family. Oxford: Oxford University Press. 
McGlynn, C. 2006. Families and the European Union: law politics and pluralism. Cambridge: Cambridge University Press.

McNeil, C and Hunter, J. 2014. The generation strain: collective solutions to care in an ageing society. London: Institute for Public Policy Research.

Pierson, P. (Ed.) 2001. The new politics of the welfare state. Oxford: Oxford University Press.

Pollack, M. A. and Hafner-Burton, E. 2000. Mainstreaming gender in the European Union. Journal of European Public Policy, 7 (3), 432-456.

Rees, T. 1998. Mainstreaming equality in the European Union: education, training and labour market policies. London: Routledge.

Schroeder, B., Macdonald, J. and Shamian, J. 2012. Older workers with caregiving responsibilities: a Canadian perspective on corporate caring. In: Ageing International, 37, 3956.

Stratigaki, M. 2004. The Co-optation of gender concepts in EU policies: the Case of “reconciliation of work and family". Social Politics, 11 (1), 30-56.

Streeck, W. (1996) Neo-voluntarism: a new European social policy regime? In G. Marks, F.W.Scharpf, P.C. Schmitter, and W. Streeck, (Eds.) Governance in the European Union, London: Sage.

Weldon-Johns, M. (2013) 'EU work-family policies: challenging parental roles or reinforcing gendered stereotypes?' European Law Journal, 19 (2), 1-20. 
